\title{
Breeding bird response to partially harvested riparian management zones
}

\author{
Christopher J. Chizinski ${ }^{\mathrm{a}, *, 1}$, Anna Peterson ${ }^{\mathrm{b}}$, JoAnn Hanowski ${ }^{\mathrm{b}}$, Charles R. Blinn ${ }^{\mathrm{c}}$, \\ Bruce Vondracek ${ }^{\mathrm{d}}$, Gerald Niemi ${ }^{\mathrm{b}}$ \\ a Minnesota Fish and Wildlife Cooperative Research Unit, University of Minnesota, St Paul, MN 55108, USA ${ }^{2}$ \\ ${ }^{\mathrm{b}}$ Natural Resources Research Institute, 5013 Miller Trunk Hwy, Duluth, MN 55811, USA \\ ${ }^{c}$ Department of Forest Resources, University of Minnesota, 1530 Cleveland Ave. North, St. Paul, MN 55108, USA \\ d US Geological Survey, Minnesota Cooperative Fish E Wildlife Research Unit, University of Minnesota, 1980 Folwell Ave., St. Paul, MN 55108, USA ${ }^{2}$
}

\section{A R T I C L E I N F O}

\section{Article history:}

Received 21 December 2010

Received in revised form 7 February 2011

Accepted 8 February 2011

Available online 5 March 2011

\section{Keywords:}

Early successional bird species

Mature forest bird species

Partial timber harvest

Riparian management

\begin{abstract}
A B S T R A C T
We compared avian communities among three timber harvesting treatments in 45 -m wide even-age riparian management zones (RMZs) placed between upland clearcuts and along one side of first- or second-order streams in northern Minnesota, USA. The RMZs had three treatments: (1) unharvested, (2) intermediate residual basal area (RBA) (targeted goal $11.5 \mathrm{~m}^{2} / \mathrm{ha}$, realized $16.0 \mathrm{~m}^{2} / \mathrm{ha}$ ), and (3) low RBA (targeted goal $5.7 \mathrm{~m}^{2} / \mathrm{ha}$, realized $8.7 \mathrm{~m}^{2} / \mathrm{ha}$ ). Surveys were conducted one year pre-harvest and three consecutive years post-harvest. There was no change in species richness, diversity, or total abundance associated with harvest but there were shifts in the types of birds within the community. In particular, White-throated Sparrows (Zonotrichia albicollis) and Chestnut-sided Warblers (Dendroica pensylvanica) increased while Ovenbirds (Seiurus aurocapilla) and Red-eyed Vireos (Vireo olivaceus) decreased. The decline of avian species associated with mature forest in the partially harvested treatments relative to controls indicates that maintaining an unharvested RMZ adjacent to an upland harvest may aid in maintaining avian species associated mature forest in Minnesota for at least three years post-harvest. However, our observations do not reflect reproductive success, which is an area for future research.
\end{abstract}

(C) 2011 Elsevier B.V. All rights reserved.

\section{Introduction}

Riparian forests connect upland forests to aquatic ecosystems along an ecotonal gradient. As a result, riparian forests are characterized by high species diversity and productivity (Naiman et al., 1993; Naiman and Décamps, 1997). Timber harvesting, as for many disturbances, has the potential to impact diverse riparian communities within the gradient. Therefore, tree basal area is often retained adjacent to waterbodies to mitigate disturbance (Darveau et al., 1995; Machtans et al., 1996; Blinn and Kilgore, 2001). These areas are known as "riparian management zones" (RMZs) and have received considerable attention for mitigating disturbance.

Most research focuses on the effects of harvested versus unharvested RMZs (Chambers et al., 1999; Schieck et al., 2000; Hanowski et al., 2003; Hanowski et al., 2007) or the widths of RMZs (Lee et al., 2004; Shirley and Smith, 2005) on birds. Hanowski et al. (2005)

\footnotetext{
* Corresponding author. Tel.: +1 4024728136.

E-mail address: cchizinski2@unl.edu (C.J. Chizinski).

1 Current address: Nebraska Cooperative Fish and Wildlife Research Unit, School of Natural Resources, University of Nebraska, Lincoln, NE, USA.

2 The Unit is jointly sponsored by the U.S. Geological Survey, The University of Minnesota, The Minnesota Department of Natural Resources, The U.S. Fish and Wildlife Service, and the Wildlife Management Institute.
}

is one of the few replicated experimental studies that examined varying levels of residual basal area. They found that more edge and early successional species and individuals colonized harvested RMZs after harvest. By contrast, the number of mature forest birds declined in harvested RMZs, but remained high in unharvested RMZs. Thus, retaining higher RBA (residual basal area) in harvested RMZs decreased the impact on the pre-harvest avian community. However, Hanowski et al. (2005) only tested a basal area retention level of $7-10 \mathrm{~m}^{2} /$ ha basal area. It remains unknown whether further benefits to the mature forest bird community occur at basal area retention levels that are greater than $7-10 \mathrm{~m}^{2} / \mathrm{ha}$.

There are $3000 \mathrm{~km}^{2}$ of forest within $30 \mathrm{~m}$ of lakes or streams in Minnesota (Hanowski et al., 2001) and although this amounts to about $1 \%$ of the total area of the state, these riparian areas offer important ecological and economic benefits. Thus, the objective of our study was to experimentally determine breeding avian response to three harvesting treatments within RMZs: (1) unharvested, (2) intermediate RBA ( $\left.11.5 \mathrm{~m}^{2} / \mathrm{ha}\right)$, and (3) low RBA $\left(5.7 \mathrm{~m}^{2} / \mathrm{ha}\right)$. We also wished to link the avian community response after harvest with changes in vegetation, assess the effectiveness of Minnesota's voluntary forest management guidelines for maintaining breeding bird communities in riparian areas (Minnesota Forest Resources Council, 1999), and compare avian response with other taxa. 
Table 1

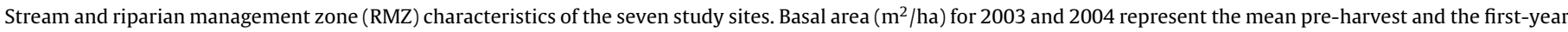
post-harvest values, respectively.

\begin{tabular}{|c|c|c|c|c|c|c|}
\hline Site & Stream name & Stream width $(\mathrm{m})$ & Stream substrate & 2003 basal area & 2004 basal area & Pre-harvest forest cover types \\
\hline 1 & Shotley Brook & 4.6 & Sand & 38.0 & 23.7 & Northern hardwoods, aspen, lowland hardwoods \\
\hline 2 & Nemadji State Forest & 0.9 & Gravel, rock & 23.3 & 12.9 & Northern hardwoods, aspen \\
\hline 4 & West Split Rock River & 5.2 & Rock & 16.6 & 7.3 & Birch, aspen, lowland hardwoods, balsam fir \\
\hline 5 & East Branch of Beaver River & 4.6 & Rock, bedrock & 28.7 & 18.1 & Birch, balsam fir, aspen \\
\hline 6 & East Baptism River & 0.9 & Sand, gravel & 27.8 & 18.1 & Aspen, birch, balsam fir \\
\hline 7 & Cloquet River Tributary & 0.6 & Gravel, rock & 24.0 & 9.0 & Northern hardwoods, aspen, lowland hardwoods \\
\hline 8 & St. Louis River Tributary & 4.6 & Sand & 37.4 & 8.5 & Northern hardwoods, aspen, lowland hardwoods \\
\hline
\end{tabular}

\section{Methods}

\subsection{Study area and treatments}

The study sites were located along seven streams within the Laurentian Mixed Forest Province in Northern Minnesota, characterized as a broad ecotone between the eastern deciduous forest and boreal forest biomes (Table 1, Fig. 1). Major tree species composition pre-harvest consisted of paper birch (Betula papyrifera), trembling aspen (Populus tremuloides), balsam fir (Abies balsamea), black ash (Fraxinus nigra), sugar maple (Acer saccharum), red maple (Acer rubrum), and basswood (Tilia americana). Less common tree species included white spruce (Picea glauca), black spruce (Picea mariana), American elm (Ulmus americana), big-toothed aspen (Populus grandidentata), balsam poplar (Populus balsamifera), yel- low birch (Betula alleghaniensis), silver maple (Acer saccharinum), and eastern white pine (Pinus strobus).

Each study site included a RMZ established between upland clearcuts and each stream. Mean preharvest basal area among all the sites was $18.4 \mathrm{~m}^{2} /$ ha. The RMZs had three treatments: (1) unharvested (hereafter "control"), (2) intermediate residual basal area (targeted goal of $11.5 \mathrm{~m}^{2} / \mathrm{ha}$ ), or (3) low residual basal area (targeted goal of $5.7 \mathrm{~m}^{2} / \mathrm{ha}$ ). The intermediate and low levels of residual basal area represent the middle and lower end of the recommended range of values for even-age management within Minnesota's forest management guidelines (Minnesota Forest Resources Council, 1999). Streams were typical of first- and second-order low gradient streams, ranging from 0.5 to $5.0 \mathrm{~m}$ in width. This study was initiated in 2003 (pre-harvest) and concluded in 2006 (three years post-harvest).

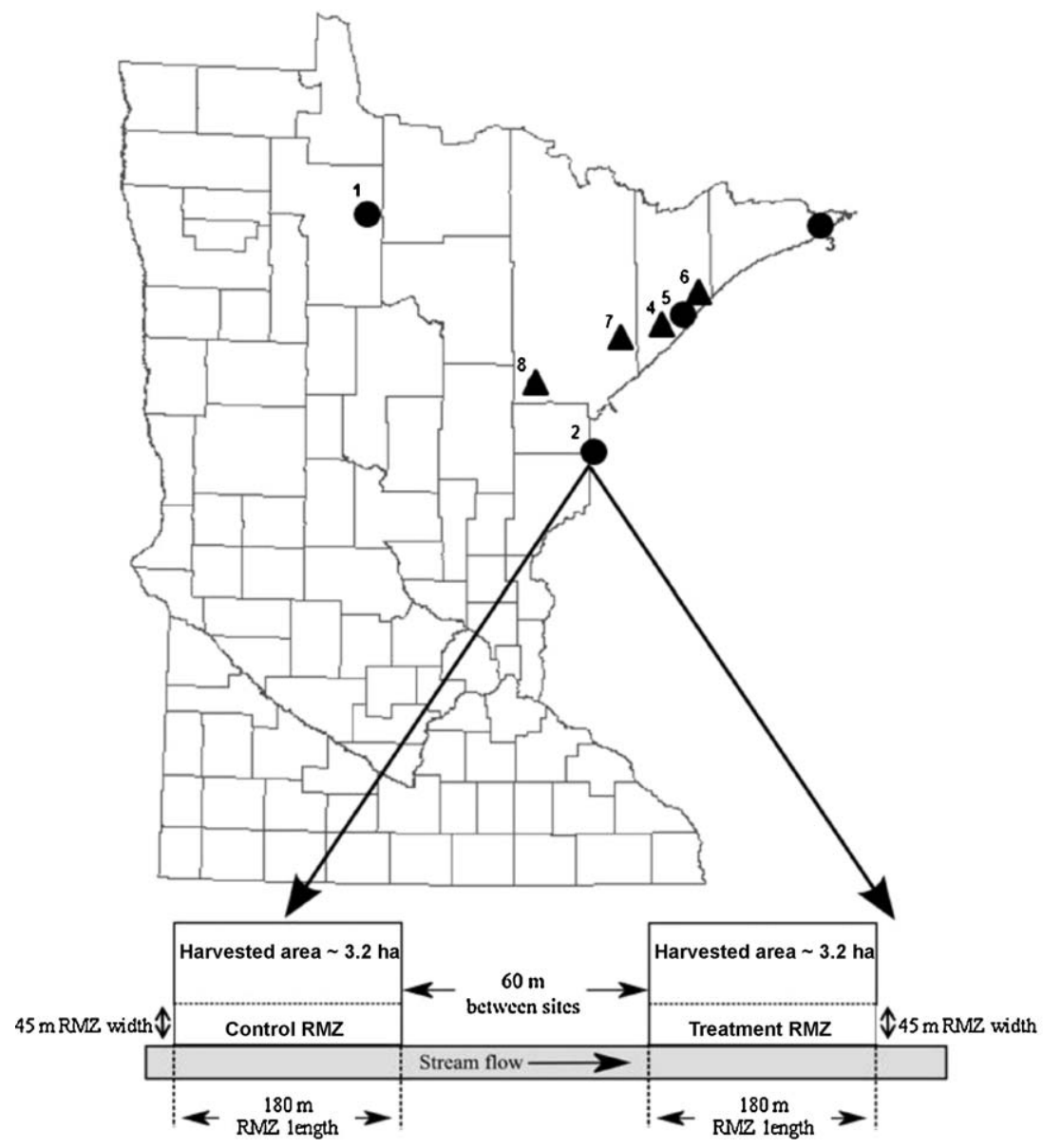

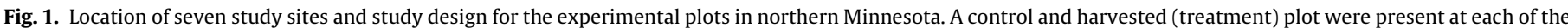

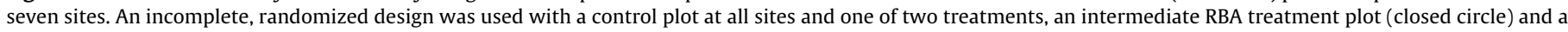

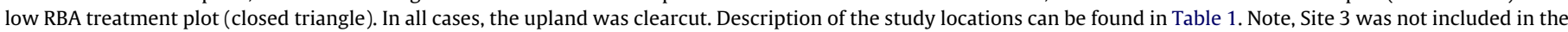
analyses. 
We used an incomplete block design with the control and one of the two harvested treatments (intermediate RBA and a low RBA) nested within each site. In all cases, the upland was clearcut. Clearcut was defined as retaining a RBA less than $3.5 \mathrm{~m}^{2} /$ ha to meet the silviculture goal of regenerating aspen (Populus spp.) as suggested by Perala (1977). The intermediate RBA treatment was replicated three times and the low RBA treatment was replicated four times. For both the intermediate and low RBA treatments, study personnel marked merchantable trees for removal. Note that while the intermediate RBA treatment was replicated a fourth time (Site 3), that treatment was completed one year after the other treatments and was removed from this analysis. Each harvested plot was 3.2 ha located on one side of the stream and had a minimum of $180-\mathrm{m}$ of stream length. The RMZ was $180-\mathrm{m}$ long and $45-\mathrm{m}$ wide. All treatment plots were separated by a minimum of $60 \mathrm{~m}$ of unharvested forest and all RMZ-harvested plots were downstream from the control plots. Timber harvesting commenced in mid-December 2003 and was completed by March 2004. All harvest operations were conducted on frozen ground when sufficient snow had accumulated, using conventional harvesting equipment (feller-buncher and grapple skidder).

\subsection{Avian surveys}

Avian surveys were conducted at each site, one year pre-harvest and for three consecutive years post-harvest during each of the three breeding season months (May-June-July). Surveys occurred within four hours of sunrise during favorable weather conditions (no rain and winds less than $20 \mathrm{kph}$ ). Survey transects, as suggested by Hanowski et al. (1990), were established in the center of RMZs and parallel to the study stream. All birds seen or heard within the 45-m RMZ (22.5 $\mathrm{m}$ on either side of the transect) were recorded. Surveys were completed by experienced observers who passed both an avian identification test and hearing test, and received training to standardize counts (Hanowski and Niemi, 1995). Analysis was completed on the maximum monthly count during May, June, and July.

\subsection{Habitat data}

Habitat data for each site were obtained from Olszewski (2009). These data included tree biomass, shrub biomass, and herbaceous biomass. Above ground biomass for each structural layer was obtained by either destructive sampling (herbaceous) or by the use of published allometric biomass equations (trees and shrubs) from study areas with similar species composition in Minnesota (see list of references in Kastendick, 2005). Herbaceous biomass $\left(\mathrm{H}_{\text {bio }}\right)$ samples of less than $0.76 \mathrm{~m}$ tall in two subplots, ( 0.61 by $0.61 \mathrm{~m}$ each) were clipped at the time of peak standing crop biomass, separated, and oven-dried at $70^{\circ} \mathrm{C}$ to a constant weight. Further detail on the habitat data collection methods can be found in Kastendick (2005) and Olszewski (2009). Habitat data were collected in 2003, 2004, and 2006. The missing values for 2005 were estimated by linear interpolation from one year prior (2004) and one year after (2006).

\subsection{Data analysis}

We examined the response of avian count, avian diversity (Shannon $\mathrm{H}^{\prime}$ ), Margalef's index of species richness, and avian-forest type associations: mature forest avian species (proportion of total count; arcsine square-root transformed) and early successional avian species (proportion of total count; arcsine square-root transformed) using repeated measures with the lme 4 package (Bates and Maechler, 2009) in R (R Development Core Team, 2008). Specifically, we modeled the avian community metrics as a function of treatment (TRT), year since harvest (YearSince) and the associated
Table 2

Results from mixed model analyses on breeding bird metrics in northern Minnesota following timber harvesting. Treatment effects within the riparian management zone (RMZ) were control (unharvested RMZ) and intermediate residual basal area (RBA) and low RBA. Count, Shannon diversity index, and Margalef's index of species richness.

\begin{tabular}{|c|c|c|c|c|}
\hline Effect & Parameter & DF & $F$ value & $P$ value \\
\hline \multirow[t]{3}{*}{ Count } & YearSince & 3 & 0.260 & 0.854 \\
\hline & TRT & 2 & 1.245 & 0.298 \\
\hline & YearSince:TRT & 6 & 0.704 & 0.648 \\
\hline \multirow[t]{3}{*}{ Diversity } & YearSince & 3 & 0.801 & 0.500 \\
\hline & TRT & 2 & 1.102 & 0.341 \\
\hline & YearSince:TRT & 6 & 0.901 & 0.503 \\
\hline \multirow[t]{3}{*}{ Richness } & YearSince & 3 & 0.247 & 0.863 \\
\hline & TRT & 2 & 0.520 & 0.598 \\
\hline & YearSince:TRT & 6 & 0.668 & 0.676 \\
\hline \multirow[t]{3}{*}{ \%Mature } & YearSince & 3 & 16.576 & $<0.001$ \\
\hline & TRT & 2 & 1.346 & 0.271 \\
\hline & YearSince:TRT & 6 & 2.174 & 0.064 \\
\hline \multirow[t]{3}{*}{ \%Early } & YearSince & 3 & 14.377 & $<0.001$ \\
\hline & TRT & 2 & 1.113 & 0.338 \\
\hline & YearSince:TRT & 6 & 1.171 & 0.339 \\
\hline \multirow[t]{3}{*}{ Turnover } & YearSince & 3 & 0.20 & 0.820 \\
\hline & TRT & 2 & 3.82 & 0.030 \\
\hline & YearSince:TRT & 6 & 0.20 & 0.940 \\
\hline
\end{tabular}

interaction. A significant interaction between treatment and year was assumed to indicate a significant harvesting affect. Each treatment was nested within site (a random effect). Significance of all analyses was assumed at $\alpha=0.05$.

We examined changes in the dominance or evenness of the avian community over time for each of the treatment groups using rank-count curves (Whittaker, 1965; Magurran, 2004). Rank-count curves were generated for each treatment and each year using the BiodiversityR (Kindt and Coe, 2005) package for R. We visually inspected the proportional count $\left(p_{i}\right)$ for each taxon plotted against the corresponding taxonomic count ranking $\left(r_{n}\right)$. To test for statistical differences in community similarity between treatments, an ANOVA using distance matrices (i.e., Bray-Curtis) was performed by the 'adonis' function (vegan package, Oksanen et al., 2008) in the R statistical software. The function 'adonis' is more robust than analysis of similarity (ANOSIM) and allows simultaneous analysis of multiple treatments and their interactions (Oksanen et al., 2008). The significance of the test is accomplished using $F$-tests based on sequential sums of squares from permutations $(n=999)$ of the data.

Avian community turnover (Russell et al., 1995; McKinney and Drake, 2001) was calculated for each year following harvest. Turnover (TO) was described by the number of species gained $\left(S_{G}\right)$ plus species lost $\left(S_{L}\right)$ divided by pre-harvest taxa richness $\left(R_{0}\right)$ plus taxa richness $i$ years post-harvest $\left(R_{i}\right)$. Turnover was calculated in comparison to the pre-harvest time period to indicate changes from and return to pre-harvest community composition.

Multivariate ordination (non-metric multidimensional scaling; NMDS) was used to explore the relationship of the treated (i.e., intermediate and low) and control sites and associated habitat factors to the avian community. Prior to ordination, the avian community was reduced to 27 species by retaining each individual species' maximum monthly count during May, June, or July and removing those species that contributed less than $1 \%$ to the total count. All counts were log transformed $(x+1)$. The NMDS ordination was created using the 'metaMDS' function in the vegan package for R. The 'metaMDS' procedure was used with default options that included the use of Bray-Curtis dissimilarity index and a maximum 20 random starts in search of a stable solution. The ordination was 

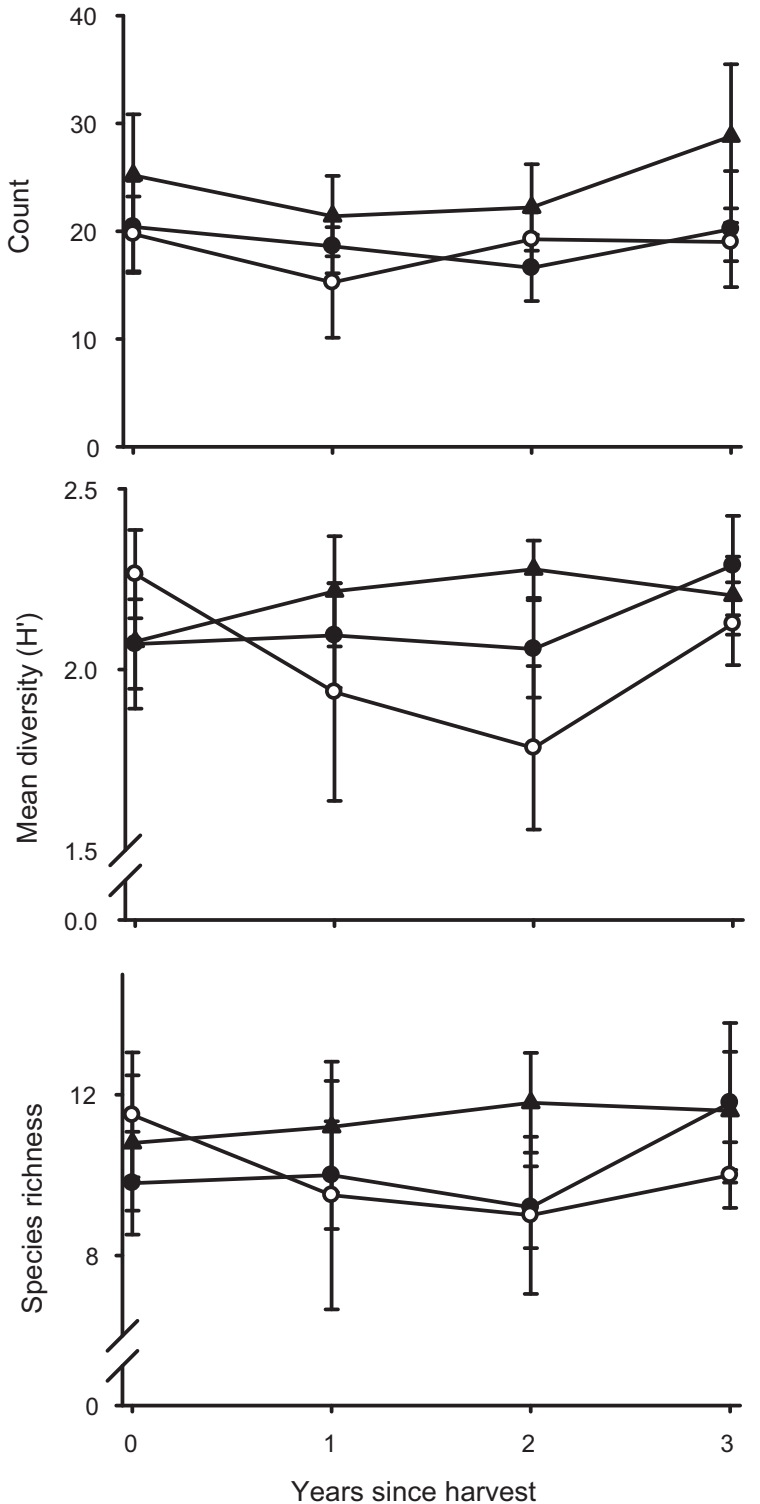

Fig. 2. Mean ( \pm standard error) count, Shannon diversity index ( $\left.\mathrm{H}^{\prime}\right)$, and species richness for birds in experimental plots in northern Minnesota. The control = closed triangles, intermediate residual basal area $(R B A)$ treatment = closed circles, and low RBA treatment $=$ open circles.

evaluated by the correlation between fitted vectors and ordination values $\left(R^{2}\right)$. To help describe the relationship of the bird ordination to the changes in tree, shrub, and herbaceous biomass, we overlaid these variables on the NMDS plot. The fitted smooth surfaces on the ordination were calculated using generalized additive models (GAM) with thin-plate splines (based on the 'ordisurf' function in the vegan package; Oksanen et al., 2008).

\section{Results}

\subsection{Realized changes in tree basal area}

The targeted timber harvest goal was $11.5 \mathrm{~m}^{2} /$ ha in the intermediate RBA treatments, but due to harvesting logistics the realized mean was $16.0 \mathrm{~m}^{2} /$ ha. Likewise, the targeted timber harvest goal was $5.7 \mathrm{~m}^{2} /$ ha in the low RBA treatments but the realized mean was $8.7 \mathrm{~m}^{2} /$ ha.
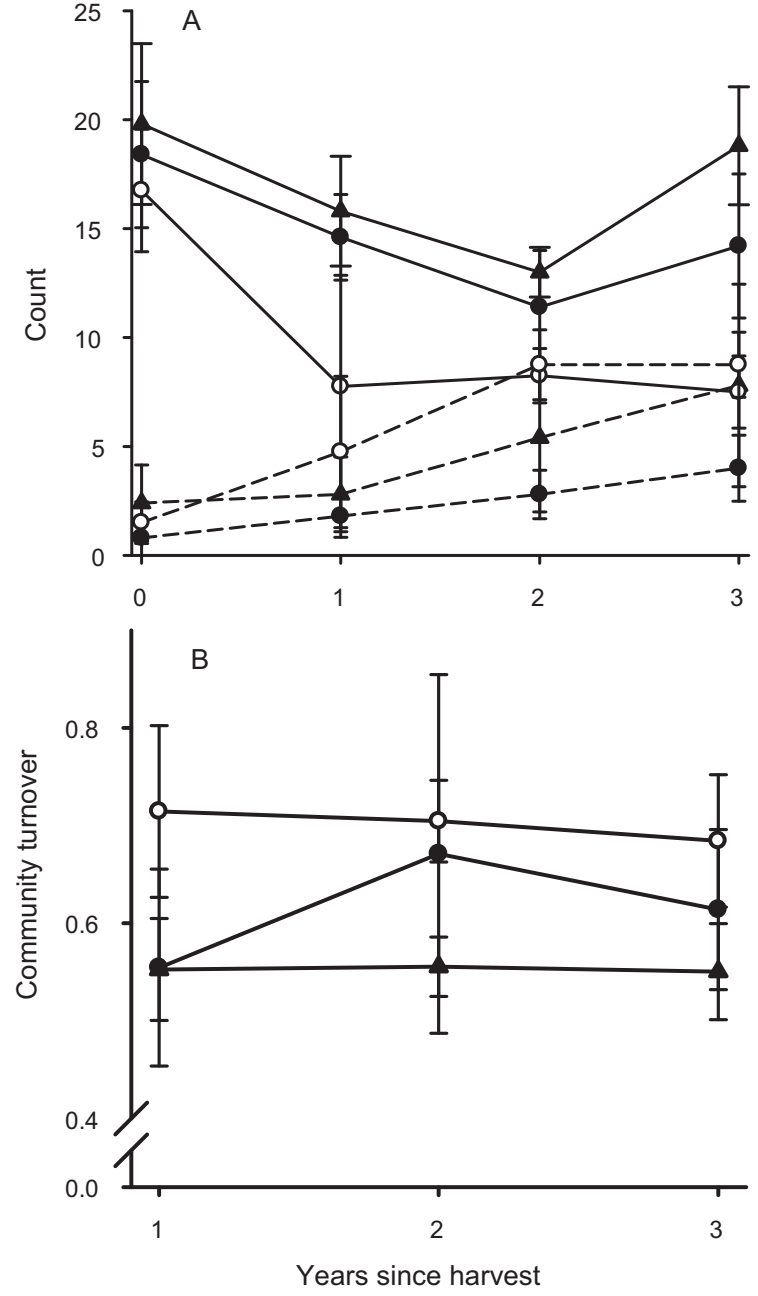

Fig. 3. Mean ( \pm standard error) for (A) count of mature forest avian species (solid line) and early succession avian species (dashed line) and (B) community turnover calculated in relation to the pre-harvest community (2003). The control=closed triangles, intermediate residual basal area $(\mathrm{RBA})$ treatment $=$ closed circles, and low RBA treatment $=$ open circles.

\subsection{Changes in the avian community}

A total of 64 bird species were identified in this study, with 56 identified in the control sites and 56 in the treatment sites, with 48 species in common to both treatment and control sites (Appendix A). The most abundant species found before harvest among all the sites was the Ovenbird (Seiurus aurocapilla), which accounted for $16 \%$ of the total avian count. Red-eyed Vireo (Vireo olivaceus) and Least Flycatcher (Empidonax minimus) accounted for $13 \%$ and $11 \%$ of the pre-harvest count, respectively. In contrast, White-throated Sparrow (Zonotrichia albicollis) was one of the rarest species accounting for $1 \%$ of the total count prior to harvest. There were no significant treatment, temporal, or associated interaction effects on species counts, species richness, or species diversity (Table 2, Fig. 2, all $P>0.05$ ). There were no harvestrelated effects among the proportion of early successional avian species or proportion of mature forest avian species (Table 2 , Fig. 3). Analysis of community turnover indicated significant treatment effects, but no significant temporal or interaction effects (Table 2).

There were changes among specific species in the avian community. Among the control sites, the Ovenbird was the most dominant species until three years post-harvest when the Oven- 

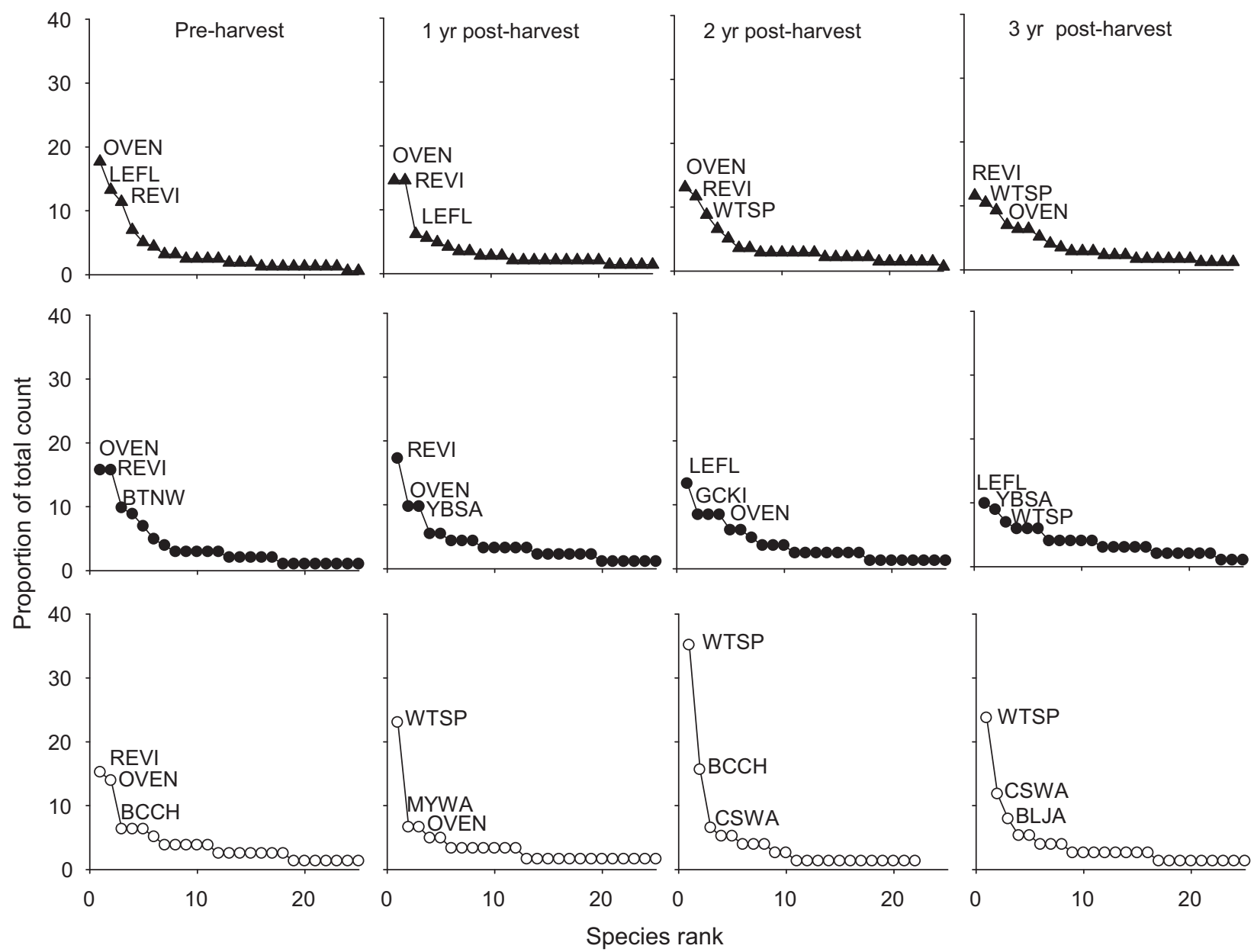

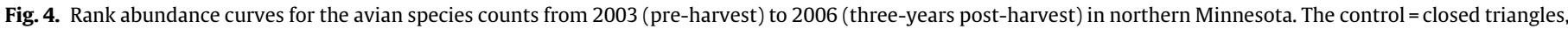

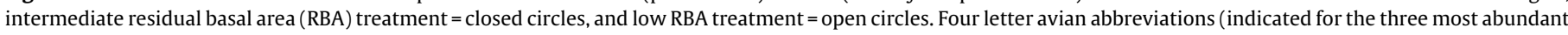
species on each curve) can be found in Appendix A.

bird decreased from $18 \%$ of the total count to $9 \%$ (Fig. 4). The Least Flycatcher also decreased post-harvest from $13 \%$ of the total count at pre-harvest to $4 \%$ at two years post-harvest and then exhibited a slight increase to $6 \%$ at three-year post-harvest. The Veery (Catharus fuscescens) represented $7 \%$ of the total count at control sites pre-harvest and decreased to $2 \%$ three years post-harvest. At two and three-year post-harvest, we observed an increase in the White-throated Sparrow count, from less than $1 \%$ of the total count at pre-harvest to $9 \%$ and $11 \%$ of the total count, respectively.

As for the control sites, the intermediate RBA treatment sites displayed an increase in the White-throated Sparrow from $0 \%$ to $7 \%$ of the total count three years post-harvest. Least flycatchers also increased from $9 \%$ of the total count pre-harvest to the most numerically dominant species at two and three-year post-harvest (Fig. 4). Ovenbird and Red-eyed Vireos remained the numerically dominant species at one year post-harvest and remained stable at two years post-harvest ( $8 \%$ of total). At three years post-harvest, Ovenbirds and Red-eyed Vireos declined to $4 \%$ and $6 \%$ of the total count, respectively, and the Least Flycatchers and Yellow-bellied Sapsuckers (Sphyrapicus varius) were the numerically dominant species ( $10 \%$ and $9 \%$ of total count, respectively).

The low RBA treatment sites indicated the greatest change in the avian community (Fig. 4). In the low RBA sites, Red-eyed Vireo and Ovenbird were the most dominant species (15\% and $14 \%$, respectively) prior to harvest, but at three years post-harvest Red-eyed Vireos were not observed in the community and the Ovenbird had declined to $3 \%$ of the total count. In contrast, White- throated Sparrows that were not found in the avian community and Chestnut-sided Warblers (Dendroica pensylvanica) that were $6 \%$ of total count before harvest increased to $24 \%$ and $12 \%$, respectively, at three years post-harvest.

The above patterns were supported by the 'adonis' analysis, which indicated a significant effect of treatment $\left(F_{2,55}=4.21\right.$, $P=0.001)$ and $\left(F_{3,55}=1.81, P=0.01\right)$ and time but there was no significant treatment $\times$ time interaction. The absence of an interaction indicates that the difference among the avian communities may be different due to natural variation among treatments and that these communities changed over time, but this change was not necessarily due to harvesting. Partial $R^{2}$ values showed that $14 \%$ of the variation in species composition was explained by the treatments and $4 \%$ was explained by the years since harvest.

\subsection{Relationship of avian community to vegetation}

Scree plots indicated that a three-dimensional solution best fit the bird community data for the NMDS ordination with a final stress of 17.7. The NMDS ordination was significantly $(P<0.001)$ correlated with tree biomass, shrub biomass and herbaceous biomass, and among the three axes, axis 1 and axis 2 were most strongly associated $(r>0.80)$ with tree biomass, shrub biomass and herbaceous biomass. As such, we fit the habitat vectors and surfaces to these two axes (Fig. 5).

The fitted surface for tree biomass had the strongest $R^{2}$ of 0.58 , and the linear $R^{2}$ was 0.50 . Tree biomass increased from the upper 

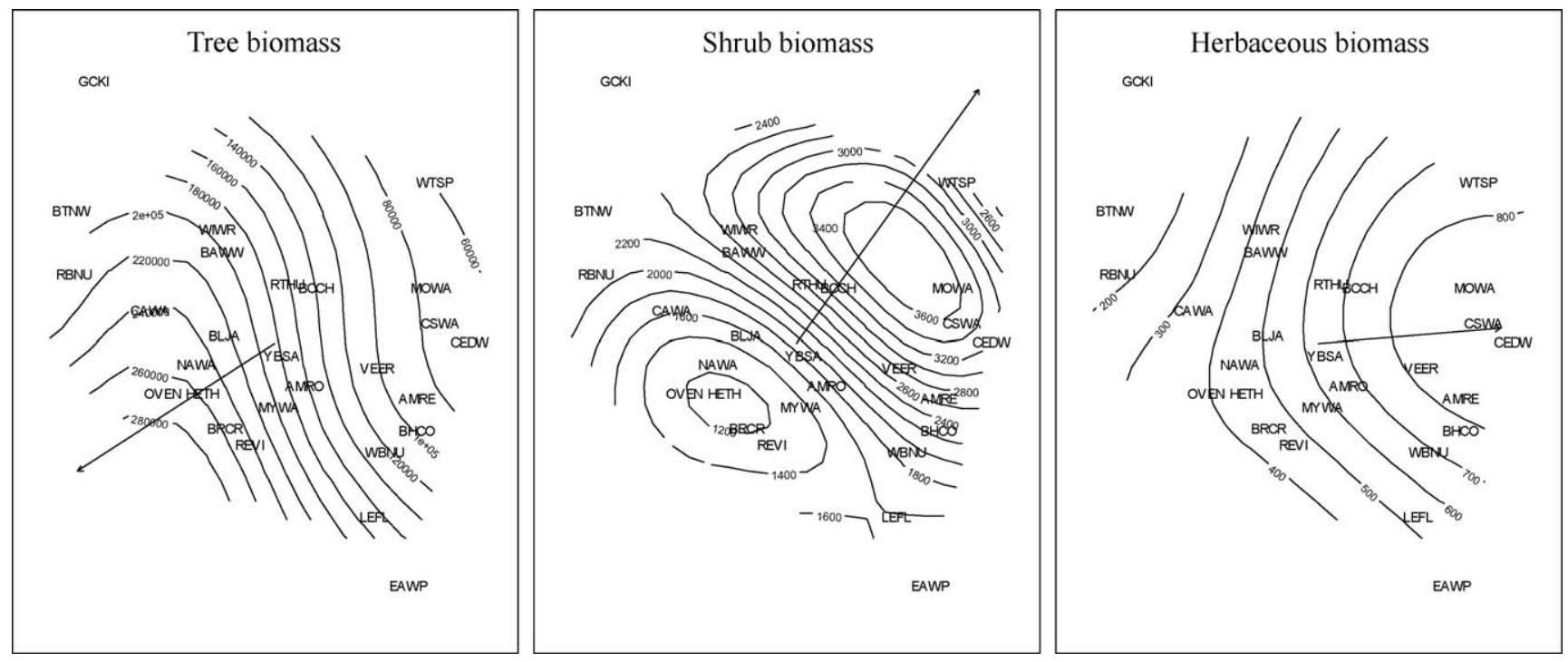

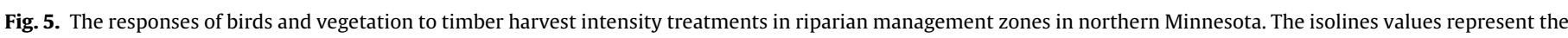

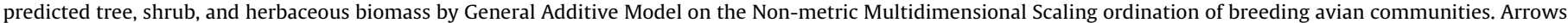
indicate the strongest linear gradient along the isolines. Four letter avian abbreviations can be found in Appendix A.

right to the lower left. The Ovenbird, Hermit Thrush (Catharus guttatus), Nashville Warbler (Vermivora ruficapilla), Brown Creeper (Certhia americana), and Red-eyed Vireo were associated with high tree biomass levels. At the opposite end of the spectrum, the Whitethroated Sparrow was primary associated with the lowest level of tree biomass. Shrub and herbaceous biomass had similar fitted surface $R^{2}$ of 0.41 and 0.41 , respectively, and linear $R^{2}$ of 0.27 and 0.35 , respectively and tended to increase in opposition to tree biomass (i.e., decreased levels of tree biomass associated with increased shrub and herbaceous biomass). The bird associations with shrub biomass are opposite to that observed with tree biomass, in that we observed greater White Throated Sparrows with greater shrub biomass. Herbaceous biomass tended to increase from left to right on the fitted surface. The bird species associated with the greater herbaceous biomass were Mourning Warbler (Oporornis philadelphia), Chestnut-sided Warbler, Cedar Waxwing (Bombycilla cedrorum), Veery, and American Redstart (Setophaga ruticilla). Golden-crowned Kinglet (Regulus satrapa), Black-throated Green Warbler (Mniotilta varia), and Red-breasted Nuthatch (Sitta canadensis) were associated with the least herbaceous biomass.

\section{Discussion}

The avian metrics investigated in this study (i.e., count, diversity, and richness) or turnover and community composition did not indicate treatment effects among the experimental treatments. As such, the changes observed in the avian community composition were marked by the replacement of mature forest avian species by early successional avian species. This change in the avian community was observed to varying degrees in all treatments. Three years after harvest, the two common early successional avian species, White-throated Sparrows and Chestnut-sided Warblers, increased in abundance and quickly numerically dominated the avian community. The White-throated Sparrow, and other early successional species, are attracted to areas with understory woody biomass because they are morphologically best adapted to use this habitat for foraging (Niemi, 1985). The greatest increase in count of these two species was observed in the low RBA treatments, which was associated with the greatest decrease in basal area and increased understory woody biomass Olszewski (2009). As previous studies have described (DeGraaf and Yamasaki, 2003; Holmes and Pitt, 2007), this turnover in the avian community would be expected with the change in vegetation following harvest and these early successional avian species will likely continue to occur in the harvested RMZs for many years. However, White-throated Sparrows also colonized unharvested RMZs. As early successional avian species, White-throated Sparrow colonized the upland clearcuts and these birds also utilized the unharvested RMZ edges and interior if sunlight penetration caused early successional vegetation to grow in once shaded areas. This is supported by the results of the ANOVA on distance matrices that indicated differences among treatments and time but no harvest effects. If the early successional bird species were colonizing the unharvested riparian $R M Z$, then there would be little indication of differences associated with harvest because all treatments were equally affected. These observations illustrate the impact of the surrounding landscape on bird community composition and also suggest the RMZ width applied here may not effectively guard against edge effects, such as nestpredation and cowbird parasitism (Hawrot and Niemi, 1996).

Our study suggests that the range of RBAs suggested by Minnesota's riparian management guidelines is inadequate to maintain abundance of mature forest bird species in RMZs. We found that the number of Ovenbirds and Red-eyed Vireos in particular, known mature forest associates, dropped after two years post-harvest in low and intermediate RBA RMZs and remained below pre-harvest levels throughout the remainder of the study until three years post-harvest. By contrast, these mature forest species remained at pre-harvest numbers in unharvested RMZs. This result highlights the advantages of retaining unharvested RMZs for benefiting mature forest breeding birds. Minnesota's riparian guidelines recommend RBAs of $5.7-18.3 \mathrm{~m}^{2} / \mathrm{ha}$ in RMZs and we found that the composition of the avian community in our intermediate RBA treatment was different from the ones in our low RBA and unharvested treatments. In particular, numbers of Least Flycatchers and Yellowbellied Sapsuckers responded favorably to the intermediate RBA treatment. Therefore, although the RBA in our intermediate treatment was inadequate for maintaining abundance of mature forest bird species, our study suggests that retaining $16 \mathrm{~m}^{2} /$ ha RBA (i.e., the realized RBA in our intermediate treatment) is beneficial for maintaining abundance of a distinct subset of the riparian avian 
community. Caution must be taken in interpreting our observations as the bird community is likely to continue changing post-harvest. Hanowski et al. (2007) indicated that some of the mature forest avian species found in harvested RMZs may begin to recolonize about nine-years post-harvest.

The bird community at intermediate sites, although similar to control sites, indicated a shift in count of the Least Flycatcher and Yellow-bellied Sapsucker. The dominance of Yellow-bellied Sapsuckers at intermediate RBA sites likely reflects an increase of suitable nest trees as nesting sites are a primary limiting factor for this species. Yellow-bellied Sapsuckers prefer live deciduous trees that are weakened by disease, wind, or insects and located in recently harvested areas (Walters et al., 2002). The shift in dominance of the Least Flycatcher was not consistent with the pattern of a decrease of mature forest avian species at intermediate sites as seen in both the Ovenbird and Red-eyed Vireo. Although considered a mature forest avian species, Least Flycatchers are commonly found in small forest patches, mid-successional forests, and near open spaces (Tarof and Ratcliffe, 2004; Tarof and Briskie, 2008). This species also forms social aggregations or territory clusters during the breeding season that appear unrelated to vegetative characteristics (Sherry and Holmes, 1985; Perry and Andersen, 2003; Tarof et al., 2005). The dominance of Least Flycatchers in intermediate sites likely reflects this aggregate behavior, as well as the species underlying relaxed habitat preference for mature forest. Hanowski et al. (2007) found a similar result at nine years postharvest where Least Flycatchers were not highly associated with the uncut riparian areas but were associated with areas that likely reflected mid-successional forests at that time.

Mature forest avian species, such as the Ovenbird and Redeyed Vireo, declined with increasing rates of timber harvesting in even-age management RMZs, and yet continued to be abundant in the control sites. This observation is also consistent with other studies (Hanowski et al., 2005; Holmes and Pitt, 2007) that found similar responses of the mature forest avian species to timber harvesting. The Ovenbird, a species that we observed to have a significant decline following harvest in all treatment plots, is a "species of greatest conservation need" in the Minnesota Department of Natural Resources' Comprehensive Wildlife Conservation Plan (Minnesota Department of Natural Resources, 2006). The Ovenbird is dependent on mature forests and forest interior habitat and thus, sensitive to timber harvesting (Lambert and Hannon, 2000; Manolis et al., 2002). Bourque and Villard (2001) observed not only lower densities of Ovenbirds where trees were partially harvested than in uncut plots, but also significantly lower reproductive performance of Ovenbirds. Bourque and Villard (2001) suggested that the effects of partial harvest (i.e., removal of approximately $30 \%$ of the basal area) on Ovenbird persistence in selection cuts may be compromised unless the harvesting intensity (i.e., degree to which basal area is reduced) is decreased or time between harvesting is maximized. The decline of mature forest avian species in the partially harvested treatments indicates that maintaining an unharvested RMZ adjacent to an upland harvest may aid in maintaining count of mature forest avian species in Minnesota. However, caution is suggested as our observations do not reflect reproductive success, only Ovenbird presence in RMZs. As riparian areas do not develop in a vacuum that is absent of natural disturbances and successional processes, their composition and structure change naturally over time. Thus, bird habitat is dynamic. Where feasible, landscape planning must consider a balance among native forest cover types, plus their age structure and landscape configuration (e.g., patch size) to provide habitat for the various bird species.

The response of the avian community within the intermediate RBA treatment differed little from the avian community within the control plots, both of which indicated striking differences to the low RBA treatments. In an analysis of the habitat response in these experimental treatments, Kastendick (2005) observed that regeneration layer biomass of shrubs and woody vegetation in clearcut uplands and low RBA treatment were more than double those of intermediate RBA or control treatments. He noted that there was a rapid response after harvest of early seral, shade-intolerant species in both the shrub and woody regenerations layers in the RMZ. The connection of avian communities to the vegetation structure is well-established (DeGraaf et al., 1998; Sanders and Edge, 1998; Pey-Yi and Rotenberry, 2005) and is one of the unifying theories in avian biology (Block and Brennan, 1993).

The changes in the avian community following timber harvesting within RMZs differed from the macroinvertebrate and fish communities under the same treatments in our experimental sites (Chizinski et al., 2010). Although harvesting to the low RBA was adequate in minimizing the effect on the aquatic system, there was indication of disruption to the avian community (this study). The choice of taxa is an important question in assessing the effects of timber harvesting in riparian communities (Lindenmayer, 1999; Lindenmayer et al., 2000), and can lead to differing and sometimes conflicting results accenting the different needs of taxonomic groups. For example, windthrow can recruit trees into the stream channel to provide a variety of ecosystem functions, such as high quality aquatic habitat for fish and macroinvertebrates (Hemstad et al., 2008) but increased windthrow decreases the amount of habitat for bird species requiring mature forest conditions. The difference in the response of the aquatic and terrestrial communities in this study area highlights the need to assess multiple taxa to understand the effects on organisms within riparian ecosystem communities.

\section{Acknowledgements}

This study benefited from the assistance of numerous individuals. Lauren Brudney, James Manolis, and Petra Wood provided helpful comments on an earlier draft of this manuscript. Funding for this project was provided by the Minnesota Forest Resources Council and the Minnesota Environment and Natural Resources Trust Fund as recommended by the Legislative-Citizen Commission on Minnesota Resources (LCCMR). The use of trade, product, industry or firm names or products or software or models, whether commercially available or not, is for informative purposes only and does not constitute an endorsement by the U.S. Government or the U.S. Geological Survey. This is contribution number 512 from the Center for Water and the Environment, Natural Resources Research Institute, University of Minnesota, Duluth.

\section{Appendix A. English and taxonomic avian species names} and guild associations for species recorded at study sites

\begin{tabular}{lll}
\hline English name & Taxonomic name & Code \\
\hline Alder Flycatcher & Empidonax alnorum & ALFL \\
American Crow & Corvus brachyrhynchos & AMCR \\
American Goldfinch & Carduelis tristis & AMGO \\
American Redstart & Setophaga ruticilla & AMRE \\
American Robin & Turdus migratorius & AMRO \\
American Woodcock & Scolopax minor & AMWO \\
Baltimore Oriole & Icteris galbula & BAOR \\
Black-and-white Warbler & Mniotilta varia & BAWW \\
Black-capped Chickadee & Poecile atricapillus & BCCH \\
Barred Owl & Strix varia & BDOW \\
Belted Kingfisher & Ceryle alcyon & BEKI \\
Brown-headed Cowbird & Molothrus ater & BHCO \\
Blue-headed Vireo & Vireo solitarius & BHVI \\
Blackburnian Warbler & Dendroica fusca & BLBW \\
Blue Jay & Cyanocitta cristata & BLJA
\end{tabular}




\begin{tabular}{|c|c|c|}
\hline English name & Taxonomic name & Code \\
\hline Brown Creeper & Certhia americana & BRCR \\
\hline Black-throated Green Warbler & Dendroica virens & BTNW \\
\hline Broad-winged Hawk & Buteo platypterus & BWHA \\
\hline Canada Warbler & Wilsonia canadensis & CAWA \\
\hline Cedar Waxwing & Bombycilla cedrorum & CEDW \\
\hline Chipping Sparrow & Spizella passerina & CHSP \\
\hline Common Grackle & Quiscalus quiscula & COGR \\
\hline Common Merganser & Mergus merganser & COME \\
\hline Common Yellowthroat & Geothlypis trichas & COYE \\
\hline Chestnut-sided Warbler & Dendroica pensylvanica & CSWA \\
\hline Downy Woodpecker & Picoides pubescens & DOWO \\
\hline Eastern Phoebe & Sayornis phoebe & EAPH \\
\hline Eastern Wood-pewee & Contopus virens & EAWP \\
\hline Evening Grosbeak & Coccothraustes vespertinis & EVGR \\
\hline Great Crested Flycatcher & Myiarchus crinitus & GCFL \\
\hline Golden-crowned Kinglet & Regulus satrapa & GCKI \\
\hline Golden-winged Warbler & Vermivora crysoptera & GWWA \\
\hline Hairy Woodpecker & Picoides villosus & HAWO \\
\hline Hermit Thrush & Catharus guttatus & HETH \\
\hline Indigo Bunting & Passerina cyanea & INBU \\
\hline Least Flycatcher & Empidonax minimus & LEFL \\
\hline Mallard & Anas platyrhynchos & MALL \\
\hline Magnolia Warbler & Dendroica magnolia & MAWA \\
\hline Mourning Warbler & Oporornis philadelphi & MOWA \\
\hline Nashville Warbler & Vermivora ruficapilla & NAWA \\
\hline Northern Parula & Parula americana & NOPA \\
\hline Northern Waterthrush & Seiurus noveboracensis & NOWA \\
\hline Orange-crowned Warbler & Vermivora celata & OCWA \\
\hline Ovenbird & Seiurus aurocapilla & OVEN \\
\hline Pine Warbler & Dendroica pinus & PIWA \\
\hline Pileated Woodpecker & Dryocopus pileatus & PIWO \\
\hline Purple Finch & Carpodacus purpureus & PUFI \\
\hline Rose-breasted Grosbeak & Pheuctuicus ludovicia & RBGR \\
\hline Red-breasted Nuthatch & Sitta canadensis & RBNU \\
\hline Ruby-crowned Kinglet & Regulus calendula & RCKI \\
\hline Red-eyed Vireo & Vireo olivaceus & REVI \\
\hline Ruby-throated Hummingbird & Archilochus colubris & RTHU \\
\hline Scarlet Tanager & Piranga olivacea & SCTA \\
\hline Song Sparrow & Melospiza melodia & SOSP \\
\hline Sharp-shinned Hawk & Accipiter striatus & SSHA \\
\hline Swainson's Thrush & Catharus ustulatus & SWTH \\
\hline Veery & Catharus fuscescens & VEER \\
\hline White-breasted Nuthatch & Sitta carolinensis & WBNU \\
\hline Winter Wren & Troglodytes troglodytes & WIWR \\
\hline Palm Warbler & Dendroica palmarum & WPWA \\
\hline White-throated Sparrow & Zonotrichia albicollis & WTSP \\
\hline Yellow-bellied Flycatcher & Emipdonax flaviventris & YBFL \\
\hline Yellow-bellied Sapsucker & Sphyrapicus varius & YBSA \\
\hline Yellow-rumped Warbler & Dendroica coronata & YRWA \\
\hline Yellow-throated Vireo & Vireo flavifrons & YTVI \\
\hline
\end{tabular}

\section{References}

Bates, D., Maechler, M., 2009. Ime4: Linear Mixed-Effects Models Using S4 Classes. R Package Version 0. 999375-32., http://CRAN.R-project.org/package=lme4.

Blinn, C.R., Kilgore, M.A., 2001. Riparian management practices: a summary of state guidelines. J. Forestry 99, 11-17.

Block, W., Brennan, L., 1993. The habitat concept in ornithology. In: Nolan Jr., V., Ketterson, E.D., Thompson, C.F. (Eds.), Current Ornithology, vol. 11. Springer, New York, pp. 35-91.

Bourque, J., Villard, M.A., 2001. Effects of selection cutting and landscape-scale harvesting on the reproductive success of two neotropical migrant bird species. Conserv. Biol. 15, 184-195.

Chambers, C.L., McComb, W.C., Tappeiner, J.C., 1999. Breeding bird response to three silvicultural treatments in the Oregon coast range. Ecol. Appl. 9, 171-185.

Chizinski, C.J., Vondracek, B., Blinn, C.R., Newman, R.M., Atuke, D.M., Fredrick, K., Hemstad, N.A., Merten, E., Schlesser, N., 2010. The influence of partial timber harvesting in riparian buffers on macroinvertebrate and fish communities in small streams in Minnesota, USA. For. Ecol. Manage. 259, 1946-1958.

Darveau, M., Beauchesne, P., Belanger, L., Huot, J., Larue, P., 1995. Riparian forest strips as habitat for breeding birds in Boreal forests. J. Wildl. Manage. 59, 67-78.

DeGraaf, R., Yamasaki, M., 2003. Options for managing early-successional forest and shrubland bird habitats in the northeastern United States. For. Ecol. Manage. $185,179-191$.

DeGraaf, R.M., Hestbeck, J.B., Yamasaki, M., 1998. Associations between breeding bird abundance and stand structure in the White Mountains, New Hampshire and Maine, USA. For. Ecol. Manage. 103, 217-233.

Hanowski, J., Danz, N., Lind, J., 2007. Breeding bird response to riparian forest management: 9 years post-harvest. For. Ecol. Manage. 241, 272-277.
Hanowski, J., Danz, N., Lind, J., Niemi, G., 2003. Breeding bird response to riparian forest harvest and harvest equipment. For. Ecol. Manage. 174, 315-328.

Hanowski, J., Danz, N., Lind, J., Niemi, G., 2005. Breeding bird response to varying amounts of basal area retention in riparian buffers. J. Wildl. Manage. 69, 689-698.

Hanowski, J., Danz, N., Lind, J., Niemi, G., Wolter, P., 2001. Wildlife Species: Responses to Forest Harvesting and Management in Riparian Stands and Landscapes. NRRI/TR-2001/02. Minnesota Forest Resources Council and National Council for Air and Stream Improvement, Saint Paul, MN.

Hanowski, J., Niemi, G., Blake, J., 1990. Statistical perspectives and experimenta design when counting birds on line transects. Condor 92, 326-335.

Hanowski, J.M., Niemi, G.I., 1995. A comparison of on-and off-road bird counts: do you need to go off road to count birds accurately? J. Field Ornithol. 66, 469-483.

Hawrot, R.Y., Niemi, G.J., 1996. Effects of edge type and patch shape on avian communities in a mixed conifer-hardwood forest. Auk 113, 586-598.

Hemstad, N.A., Merten, E.C., Newman, R.M., 2008. Effects of riparian forest thinning by two types of mechanical harvest on stream fish and habitat in northern Minnesota. Can. J. Forest Res. 38, 247-256.

Holmes, S.B., Pitt, D.G., 2007. Response of bird communities to selection harvesting in a northern tolerant hardwood forest. For. Ecol. Manage. 238, 280-292.

Kastendick, D.N., 2005. Riparian forest management in northern Minnesota: effects of riparian silvicultural treatments on forest biomass, structure, composition, and indices of plant available nutrients. Master's of Science Thesis. University of Minnesota, Saint Paul, MN.

Kindt, R., Coe, R., 2005. Tree Diversity Analysis. A Manual and Software for Common Statistical Methods for Ecological and Biodiversity Studies. World Agroforestry Centre (ICRAF), Nairobi.

Lambert, J.D., Hannon, S.J., 2000. Short-term effects of timber harvest on abundance, territory charactersitics, and paring success of Ovenbirds in riparian buffer strips. Auk 117, 687-698.

Lee, P., Smyth, C., Boutin, S., 2004. Quantitative review of riparian buffer width guidelines from Canada and the United States. J. Environ. Manage. 70, 165-180.

Lindenmayer, D.B., 1999. Future directions for biodiversity conservation in managed forests: indicator species, impact studies and monitoring programs. For. Ecol. Manage. 115, 277-287.

Lindenmayer, D.B., Margules, C.R., Botkin, D.B., 2000. Indicators of biodiversity for ecologically sustainable forest management. Conserv. Biol. 14, 941-950.

Machtans, C.S., Villard, M.A., Hannon, S.J., 1996. Use of riparian buffer strips as movement corridors by forest birds. Conserv. Biol. 10, 1366-1379.

Magurran, A.E., 2004. Measuring Biological Diversity. Blackwell Publisher, Malden, MA

Manolis, J., Andersen, D., Cuthbert, F., 2002. Edge effect on nesting success of ground nesting birds near regenerating clearcuts in a forest-dominated landscape. Auk 119, 955-970.

McKinney, M.L., Drake, J.A., 2001. Biodiversity Dynamics: Turnover of Populations, Taxa, and Communities. Columbia University Press.

Minnesota Department of Natural Resources, 2006. Tomorrow's Habitat for the Wild and Rare: An Action Plan for Minnesota Wildlife. Comprehensive Wildlife Conservation Strategy.

Minnesota Forest Resources Council, 1999. Sustaining Minnesota Forest Resources: Voluntary Site-level Forest Management Guidelines for Landowners, Loggers and Resource Managers. Minnesota Forest Resources Council, St. Paul, MN.

Naiman, R.J., Décamps, H., 1997. The ecology of interfaces: riparian zones. Annu. Rev. Ecol. S. 28, 621-658.

Naiman, R.J., Décamps, H., Pollock, M., 1993. The role of riparian corridors in maintaining regional biodiversity. Ecol. Appl. 3, 209-212.

Niemi, G.J., 1985. Patterns of morphological evolution in bird genera of New World and Old World peatlands. Ecology 66, 1215-1228.

Oksanen, J., Kindt, R., Legendre, P., O'Hara, B., Simpson, G.L., Solymos, P., Stevens, M.H.H., Wagner, H., 2008. vegan: Community Ecology Package, Version 1.16-4., http://vegan.r-forge.r-project.org.

Olszewski, S.L., 2009. Structural and compositional changes in the terrestrial vegetation of forested riparian areas following a gradient of timber harvesting regimes. Master's of Science Thesis. University of Minnesota, St. Paul.

Perala, D.A., 1977. Managers handbook for aspen in the north-central states. Technical Report NC-36. USDA Forest Service, North Central Forest Experiment Station, St. Paul, MN.

Perry, E.F., Andersen, D.E., 2003. Advantages of clustered nesting for Least Flycatchers in North-Central Minnesota. Condor 105, 756-770.

Pey-Yi, L., Rotenberry, J.T., 2005. Relationships between bird species and tree specie assemblages in forested habitats of eastern North America. J. Biogeogr. 32 1139-1150.

R Development Core Team, 2008. R: A Language and Environment for Statistical Computing. R Foundation for Statistical Computing, Vienna, Austria, Available at: http://www.Rproject.org.

Russell, G.J., Diamond, J.M., Pimm, S.L., Reed, T.M., 1995. A century of turnover: community dynamics at three timescales. J. Anim. Ecol. 64, 628-641.

Sanders, T.A., Edge, W.D., 1998. Breeding bird community composition in relation to riparian vegetation structure in the western United States. J. Wildl. Manage. $62,461-473$.

Schieck, J., Stuart-Smith, K., Norton, M., 2000. Bird communities are affected by amount and dispersion of vegetation retained in mixedwood boreal forest harvest areas. For. Ecol. Manage. 126, 239-254.

Sherry, T.W., Holmes, R.T., 1985. Dispersion patterns and habitat responses in birds in northern hardwood forests. In: Cody, M.L. (Ed.), Habitat Selection in Birds. Academic Press, London, pp. 283-310. 
Shirley, S.M., Smith, J.N.M., 2005. Bird community structure across riparian buffer strips of varying width in a coastal temperate forest. Biol. Conserv. 125, 475-489.

Tarof, S.A., Briskie, J.V., 2008. Least Flycatcher (Empidonax minimus), The Birds of North America Online. In: Poole, A. (Ed.), Cornell Lab of Ornithology, Ithaca, Retrieved from the Birds of North America Online: http://bna.birds. cornell.edu.floyd.lib.umn.edu/bna/species/099 doi:10.2173/bna.99.

Tarof, S.A., Ratcliffe, L.M., 2004. Habitat characteristics and nest predation do not explain clustered breeding in least flycatchers (Empidonax minimus). Auk 121 (3), 877-893.
Tarof, S.A., Ratcliffe, L.M., Kasumovic, M.M., Boag, P.T., 2005. Are least flycatcher (Empidonax minimus) clusters hidden leks? Behav. Ecol. 16 (1), 207-217.

Walters, E.L., Miller, E.H., Lowther, P.E., 2002. Yellow-bellied Sapsucker (Sphyrapicus varius), The Birds of North America Online. In: Poole, A. (Ed.), Cornell Lab of Ornithology, Ithaca, Retrieved from the Birds of North America Online: http://bna.birds.cornell.edu.floyd.lib.umn.edu/bna/species/662 doi:10.2173/bna.662

Whittaker, R.H., 1965. Dominance and diversity in land plant communities: numerical relations of species express the importance of competition in community function and evolution. Science 147, 250. 